\title{
Students' Perceptions of Content- and Language- Integrated Learning in Vietnam: A Survey Study
}

\author{
Phuong-Bao-Tran Nguyen ${ }^{*}$ \\ KU Leuven, Belgium \\ Can Tho University, Vietnam \\ https://orcid.org/0000-0002-2927-0632 \\ Lies Sercu \\ KU Leuven, Belgium \\ https://orcid.org/0000-0003-3213-396X
}

\begin{abstract}
Content- and language-integrated learning (CLIL), an educational approach, in which the subject matter is taught in a foreign language. This has become popular in tertiary education. Many research studies have shown its benefits and discussed the favorable effects, especially with respect to L2 language gains. Yet, critical voices, also from the primary stakeholders, namely the students taking part in such integrated programs, have also been heard. In an effort to integrate into the international academic and scientific community, universities in Vietnam have also started to teach academic courses in English. The main objective of this cross-sectional survey study $(\mathrm{N}=104)$ was to explore Vietnamese students' perceptions of such dual-training programs and to investigate to what extent they feel the program currently meets their needs. Our findings show that both lecturers and students are struggling in these courses, for one thing, because of insufficient levels of mastery of the English language; while for another reason, since courses cannot be characterized as courses in which disciplinary contents and the foreign language are taught in an integrated way. The way forward seems to be to educate the lecturers and the students well, before allowing them to participate in CLIL English courses. All these issues need to be considered in the context of local Vietnamese educational realities and traditions.
\end{abstract}

Keywords: English-Medium Instruction (EMI); Content- and LanguageIntegrated Learning (CLIL); Vietnamese Higher Education; students' perception; survey

\footnotetext{
${ }^{*}$ Corresponding author: Phuong-Bao-Tran Nguyen, npbtranctu.edu.vn
} 


\section{Introduction}

As in other countries in the Asian-Pacific Region, the Vietnamese Ministry of Education (MOET) has embraced the idea of teaching content courses in English in both upper-secondary and higher education (HE) institutions. With the Vietnamese government's release of the "Teaching and Learning Foreign Languages in the National Educational System, Period 2008-2020" project, one might say that the government has trusted the higher education sector with the extra challenge and responsibility of educating talented Vietnamese youngsters not only for the Vietnamese, but also for the global labour market. Master's in engineering or Business Administration, for example, also have to become proficient users of the English language. They have to be able to use that language flexibly and effectively for social, academic, and professional purposes. According to the Ministry of Education (MOET, 2008), on graduation, students need to be able to use a foreign language confidently and independently in communication, studies and work in an integrated, multilingual, and multicultural environment.

Since 2012, universities have started to supplement or replace English language teaching courses with English-Medium Instruction (EMI) courses. In EMI, the lecturer typically uses the English language, and rather than Vietnamese, to teach a content course. Underlying the introduction of EMI is the belief that offering courses in English within the meaningful context of learning specialized content is the ideal way to also foster students' English language skills.

Directly after the first period of MOET's "Teaching and Learning Foreign Languages in the National Educational System" came to an end, this study wanted to investigate the current EMI situation, as it is perceived by the main stakeholders: what do students perceive of teaching, their lecturers' English proficiency, EMI teaching approaches, their own motivation, and the mastery of English? Do students believe that EMI courses do not negatively affect either content or language learning? To that end, a survey study among EMI students from one university situated in the Mekong Delta was carried out. Students' perception that data can inform lecturers and university authorities on how to proceed in the future, in order to meet students' needs and MOET's expectations.

In what follows, we first frame the study, defining and assessing EMI and Content- and Language-Integrated Learning (CLIL), and discussing how CLIL is perceived by students in tertiary education. Next, we provide a general sketch of the current situation of EMI and CLIL teaching in Vietnam. This is followed by a discussion of the research methodology. In the final sections of this paper, we present and discuss our research findings. The data show that both lecturers and students are struggling in these courses, for one thing because of insufficient levels of mastery of the English language and, for another, because courses cannot be characterized as courses in which disciplinary contents and a foreign language are taught in an integrated way. 


\section{Background and Literature review}

\subsection{Content and Language Integrated Learning}

As pointed out by Macaro et al. (2018) in their systematic review of research findings regarding English-medium instruction in Higher Education (HE), EMI is used to refer to a variety of educational approaches, and "both the definition of EMI in HE and its practice appear to be fluid." (Macaro et al., 2018). Both at the macro- and at the micro-level of education, reference may be made to Content and Language-Integrated Learning (CLIL) or Integrating Content and Language in Higher Education (ICLHE). According to Marsh et al. (2012), Content- and Language-Integrated Learning refers to "any dual-focused educational context in which an additional language is used for the learning and teaching of both content and language (Marsh et al., 2012, p. 9). Teachers in a CLIL context are not typically native speakers of the foreign language or language teachers; they are experts in an academic discipline (Fajardo Dack et al., 2020). Nor are they language-teaching specialists, who master a language-teaching methodology.

From this, it follows that CLIL courses at the tertiary educational level may be closer to English-medium instruction (EMI) or Content-based instruction (CBI) courses. In such courses, students do receive large amounts of English language input, but the educational focus remains on content learning. Indeed, in tertiary education, with its focus on disciplinary knowledge and skills learning, CLIL courses tend to come closer to CBI and EMI courses, rather than to true CLIL courses, where the content is learned through language; while language is learned through content (Coyle et al., 2010; Peukert \& Gogolin, 2017).

Generally, it is assumed that the language would be learned alongside the content, and that there is no need to outline a language-learning trajectory with specific language attainment gains. Although most studies exploring language learning outcomes have found that these content-based language instruction programs to do as well, or better than non-CLIL programs (Graham et al., 2018, p. 30), it is clear that language input alone does not necessarily guarantee language acquisition and that pedagogical interventions supporting the integrated learning of language and content are needed and also beneficial.

\subsection{Student perceptions of CLIL}

As shown by Goris et al. (2019), in a systematic review of longitudinal experimental CLIL studies, CLIL learners develop better writing skills than nonCLIL learners, and additionally, their grammar and vocabulary are better developed. Significant results are found as regards their enhanced fluency in the foreign language. Indeed, fluency is the skill commonly believed to be affected most favorably because of the increased opportunity for authentic communication (Goris et al., 2019, p. 693).

Given these overall positive results, it comes as no surprise that researchers investigating students' perceptions of their CLIL experiences have found that learners at the tertiary level of education overall hold positive views of CLIL. Tsuchiya and Pérez Murillo (2015), for example, found that students in Spain and Japan expressed a relatively positive view towards CLIL in higher education ( $p$. 33). Yet, they also found that students voiced critical concerns regarding CLIL implementation at university level. These concerns include their insufficient 
English skills to understand academic subject matter and the potential risk of lacking subject knowledge in their mother tongue. Aguilar and Rodriguez (2012) report students' perceptions of some of their lecturers, as only having a low level of mastery of English. This leads to lecturers' slow delivery rate hindering smooth lecturing, which is said to be "tedious" and "difficult". Also, CLIL courses lack sufficient opportunities for discussion; since both students and lecturers do not feel at home in the foreign language and may show a tendency towards avoiding student interaction in the classroom (Aguilar \& Rodríguez, 2012, p. 193).

On the other hand, students also testify to having improved their English listening skills and mastery of specialized vocabulary. Nuñez Asomoza (2015), investigating CLIL at the BA university level in Mexico found that students have an overall positive perception of CLIL courses. However, this study also reports that participants identify many areas that could be improved as regards lecturers, materials and the learning environment in general (Nuñez Asomoza, 2015).

Students generally struggle with developing academic skills, such as academic writing, identifying and using academic genres and specialized vocabulary. In addition, they report feeling stressed and anxious in CLIL courses, something that is also due to the presence of native speakers of English in the CLIL classes. This feeling of uneasiness is further fostered by a deterioration in their academic performance because of CLIL. In addition, students remark that teachers need training in English, CLIL teaching methodology and CLIL material development, findings which Aguilar and Rodriguez (2012) also suggested.

\subsection{CLIL in Vietnam and Vietnam's new language policy in higher education}

In 2012, the Vietnamese government issued a new law on HE, allowing a foreign language to be used as the medium of instruction. This stirred up heated discussions, with many people expressing the fear of losing the country's unity and a strong Vietnamese cultural identity and heritage. Yet, it is clear that the government has initiated important changes in the national language policy and planning, opening Vietnam further to the world.

Following the release of this HE law, Vietnamese HE institutions (HEI) have established linkages with HEI abroad to develop so-called Advanced (AP), Joint (JP) and High Quality (HQP) Programs. Whereas HQP's are locally developed with reference to foreign programs, A's are designed and administered in close cooperation with international partners. Sometimes, Vietnamese students study the same curriculum as students in the partner universities. At other times, the foreign curriculum is adapted to local Vietnamese needs and circumstances. The assumption is that all teaching in these programs is done in English and that English medium foreign textbooks are to be used.

Even if the government has been successful in establishing a sense of urgency regarding the need to integrate in the international research and teaching community in HEIs, it has not been fully efficient when it comes to stimulating the necessary preparatory work that HEIs need to do before starting with such an important reform (Tran \& Marginson, 2018). Given that the students are major stakeholders in this whole endeavor, the government could have incited HEI to 
set minimum EMI course entry requirements, specifically with respect to the level of mastery of the English language.

Yet, at the national level, there is no consistency as regards the entry level requirements for students, who want to enroll in EMI programs in which at least $60 \%$ of the courses are taught in English. It is said that they should have a sufficient mastery of the English language, but no certificate of English mastery may be required, and no entry test has yet to be taken. When an English certificate is required, a limited to moderate user level, as defined by IELTS (International English Language Testing Services), or a level comparable to an A2 level (CEFR, Common European Framework of Languages) may be deemed sufficient. However, that level does not allow for easy content, comprehension or communication in the EMI content classroom.

When taking the VSTEP, the Vietnamese Standardized Test of English Proficiency, and obtaining a B2 or even a C1 score, students are led to believe that they have obtained the internationally recognized CEFR B2 or C1 level, whereas in fact, the VSTEP is a test that is mainly focused on general English communication skills. Thus, it does not reflect international standards where students at the B2 or C1 level are required to demonstrate their understanding of and ability to discuss and write complex texts on abstract topics, including technical discussions in their field of specialization.

As regards EMI lecturers, government documents require that they hold a $\mathrm{PhD}$ or a master's degree obtained from an overseas university. Yet, as demonstrated by Nguyen (Nguyen, 2018, p. 123-124), the overseas criteria can be applied loosely, and lecturers who did not study in an Anglo-Saxon environment, or did not obtain an English-medium PhD or a master's degree can also be asked to teach a course in English. Lecturers do not need to provide proof of their mastery of English at the CEFR C1-level. In addition, professional development toward better EMI teaching competence is left to the lecturer's own initiative.

Additionally, from research, it has become clear that lecturers have not been consulted, as to whether they feel up to teaching a content course in English, let alone supporting their students' development of their English language proficiency (ELP) via their course. Therefore, lecturers may not experience full ownership of the reform; and they may experience feelings of uncertainty and inadequacy (Do \& Le, 2017; Vu \& Burns, 2014). As specialists in their area of study, they may fear a language-content trade-off to the detriment of content, something which to them is not acceptable.

\section{The Methodology}

\subsection{Aim}

From the above review of the literature, it is clear that lecturers and students may be both supportive, as well as critical of CLIL education, and that local language policy-related decisions pertaining to the conditions, under which CLIL programs can co-determine their level of success. The aim of this study, then, was to explore students' perceptions of CLIL teaching in Vietnam directly after the first phase of 
the government's "Teaching and Learning Foreign Languages in the National Educational System, Period 2008-2020", whereby the project came to an end.

Using a validated questionnaire, the study aimed to answer the following research questions:

(1) What are students' perceptions of their mastery of English within EMI courses?

(2) What are students' perceptions of their lecturers' English language proficiency within EMI courses?

(3) What are students' perceptions of the amount of teaching done in English within EMI courses?

(4) What are students' perceptions of the teaching materials used in EMI courses?

(5) What are students' preferred teaching activities within EMI courses?

(6) To what extent do students feel they have been able to strengthen their English language skills during such EMI courses?

The main hypothesis of the study was that growth in students' English language proficiency would be limited; and it would depend on the amount of teaching time done in English, students' initial ELP, lecturers' ELP and the chosen teachingand-learning activities.

\subsection{The Research Instrument}

The study used a quantitative cross-sectional design (McKinley \& Rose, 2019). A self-developed and pretested questionnaire survey (see Attachment 1) was used to explore the following aspects: students' background (items 1-4), students' perceptions of their mastery of English (items 5 -7), students 'perceptions of the usefulness of teaching activities (items 8-16), students' assessment of the amount of teaching time taking place in English (item 17), students' views on whether or not CLIL education had helped them to improve their English language skills (item 18) or their content knowledge (item 19), students' perceptions of their lecturers' English language proficiency (items 20-29), and, finally, students' appreciation of teaching materials (items 30-41).

The participants responded to each statement by using a five-point scale. The survey answers were coded and checked for reliability. A strong Cronbach's Alpha (alpha 0.843) was obtained.

\subsection{Sample}

\subsubsection{Student sample}

The survey was distributed among freshmen CLIL students from one large Vietnamese public university (PU) that can be considered as being representative of other public universities in Vietnam. From all the EMI students, a randomized sample of 365 students was selected. From this sample, 104 students from diverse study backgrounds participated in the study on a voluntary basis. The participants were studying Business, ICT or Engineering.

\subsubsection{University profile}

At PU, EMI was first introduced in 2010 in the study areas 'Advanced Biotechnology' and 'Advanced Aquaculture'. To these, other disciplines were 
added in 2015, namely the areas of Information Technology and International Business. Currently, this group of pioneers has been joined by EMI programs in 'Chemistry Technology', Electricity Technology', 'Construction Technology', 'Food Technology', and 'Finance and Banking'. Following government regulations, a minimum of $60 \%$ of courses are to be fully delivered in English. Lecturers were required to have obtained a PhD, or to have graduated from an overseas master's program. However, they did not need to provide proof of a CEFR C1 level of mastery of the English language.

From a limited set of interviews with lecturers, we learned that lecturers do not receive assistance when turning their Vietnamese-medium course into an EMI course, nor has a university-wide service been put in place to which they could turn for advice on how to integrate language learning into their content teaching, or to prepare course materials so that students can learn both the language and the content from them. Lecturers use English course books published by renowned publishers; since these are considered to be reliable sources of knowledge; and also they feel that their mastery of the English language does not permit them to write equivalent teaching materials themselves.

Before 2020, students who wanted to enter an EMI program were required to take a computerized PU in specific general English placement test, designed after the TOEIC (Test of English for International Communication) test. When they did not reach a B1 level, they were required to take an intensive 20 credit English course before they could enter the EMI program in their sophomore year. After having taken the course, students were expected to have reached a B1 level in English. Since 2020, and since students from English medium high school programs, offered in Schools for the Gifted, have entered university, admission is based on the students' English and content scores obtained in three EMI high-school subjects.

\subsection{The data analysis}

The data processing was done in accordance with the GDPR-file G-2021-3393, approved by the GDPR and Ethics Commission of Katholieke Universiteit Leuven (KU Leuven). Descriptive and inferential data analyses were performed with the help of SPSS version 20.

\section{The Results}

\subsection{Students' perceptions of their mastery of English}

As regards students' self-assessment of their English language proficiency, 15\% of the students indicated that they have a level below B1, with about $12 \%$ testifying to having a level as low as A1. $27 \%$ for assessing themselves, as having acquired a B1 level, and about half of the students, as having a B2 level. Only 4\% said that they had a C1 level of ability.

When asked whether they hold a certificate testifying to their level of English, 56 students or $54 \%$ said that they do. Yet, strikingly, all these students self-assessed their actual proficiency level to be lower than that which the certificate indicated.

When inquiring into students' confidence to use English during EMI courses, one quarter $(25 \%)$ indicated that they agreed or strongly agreed with that statement. 
They reported that they never feel sufficiently confident to use English; rather they feel frightened and stressed when they do not understand their lecturer, when s/he is speaking in English; and they worry that their final results would be poor, because of that. About one third of the students took a neutral stance in these matters, from which it follows that only about half of all freshmen feel confident enough to study in English in content courses, or to participate actively in EMI courses because of their limited English proficiency.

\subsection{Students' perceptions of their lecturers' English language proficiency}

As regards students' perceptions of their lecturers' English language competence, as many as $58,5 \%$ of the students answered that they agreed or strongly agreed with their lecturers having excellent English language skills, from which it follows that no less than $41,5 \%$ indicated they did not agree with this statement.

When asked about what skills students want to find in a lecturer, they indicated that they mostly expect their lecturers to have content knowledge ( $88 \%$ of students), to be able to explain that content well ( $88 \%$ of students) and have knowledge of specialized vocabulary (75\% of students). Surprisingly, the variable that meets with the lowest overall agreement is that lecturers need to be able to use flawless English (38\% of students). The ability to reformulate or to pronounce words correctly is deemed to be more important than that of grammatical correctness, when using English.

\subsection{Students' perceptions of the amount of teaching done in English}

When asked about the amount of teaching that is done in English in EMI-courses, the picture obtained testifies to the very diverse experiences. As can be seen from Figure 1, the largest group of students (62\%) indicated that they believed their lecturers use English for at least 50 to $60 \%$ of the teaching time, with $44 \%$ of students' assessment being that most lecturers meet the $50-60 \%$ requirement put forward by PU. It follows that about $2 / 5$ or $38 \%$ of the students believed that the lecturers speak Vietnamese during about half or more than half of the teaching time.

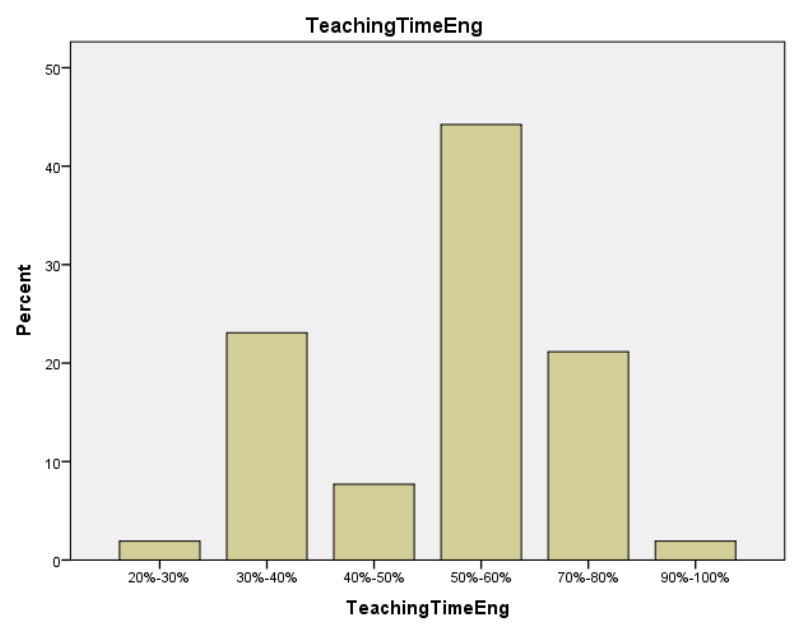

Figure 1: Students' perceptions of the amount of English used by lecturers 


\subsection{Students' perceptions of teaching materials, as fostering their English proficiency}

When asked whether their teaching materials might help them to acquire course contents and the English language equally well, 46,2\% of students said that they agreed with this statement, given that teaching materials are generally in English. Yet, more than half of the students voiced the opinion that content learning outweighs language learning. Only slightly over half of the EMI students (52\%) said they believed that their teaching materials systematically fosters their English proficiency.

\subsection{Students' perceptions of teaching activities}

When asked about the usefulness of teaching activities, the students indicated they preferred teacher-centered activities, where the lecturers give oral presentations and explain English media scientific texts, next to allowing students to discuss the contents in groups. Independent individual work, such as making oral presentations in English, was considered to be less useful, by quite a large group of freshmen (30 to $40 \%$ ).

4.6 Students' assessment of the extent to which they feel they have been able to strengthen their English language skills during EMI courses

Finally, the questionnaire asked whether the respondents believed that they have been able to improve their English language skills. As many as $69 \%$ of the students ticked the agree or strongly agree box, with none of the students strongly disagreeing with the statement; and the remaining $31 \%$ of freshmen indicating that they were not really sure about this issue.

\section{Discussion}

The findings from our survey have provided important information regarding the extent to which EMI courses can be considered CLIL courses and about how students experience their learning and teaching situation. The findings demonstrate the lack of growth in English-language proficiency among a large group of PU freshmen, thereby confirming our main hypothesis. Both lecturers and students were struggling in EMI courses, which confirms the earlier work of, for example, Nguyen (2018), Tran and Phuong (2019), and Macaro et al. (2018). In many cases, this struggle follows from lecturers' and students' insufficient level of mastery of the English language.

Our findings also indicated that EMI courses cannot be characterized as true CLIL courses, suggesting that a dual focus on both the content and the English language teaching is not yet in place. Traditional approaches to teaching (lecture format combined with group discussions, which, as it was noticed during our class observations, often take place in Vietnamese, not in English). These are preferred activities in which the students are obliged to demonstrate their personal mastery of content-and-language in an integrated way, for example during an oral presentation followed by a Q\&A session. Even if the teaching materials may be in English, too many students indicated that their proficiency in English does not substantially improve in an EMI course - thanks to more extensive purposive English language input. Students with a lower language proficiency indicated they do not always understand their lecturers; and that they feel anxious to speak 
English. A large part of their teaching is done in Vietnamese, which may either follow from lecturers' awareness of students' comprehension difficulties, or from their own lack of mastery of this medium of instruction.

Furthermore, too large a group of students indicated that they feel their current level of English does not allow them to benefit fully from EMI courses both in terms of content and language teaching, is an unfortunate finding, but this should not surprise us; since it confirms the earlier findings (Phuong \& Nguyen, 2019). When self-assessing their proficiency level, students systematically indicate that the English language certificate they obtained seems to have overrated their actual proficiency. This may follow from the fact that students have been studying for the English-language proficiency test, that they wanted to take, with many practice materials being available that could help test takers prepare specific answers to specific exam questions.

This is true for the VSTEP, and also for other international English-language tests. However, from learning answers to exam questions by heart, it does not necessarily follow that one can actually transfer vocabulary to new situations, or to use specific grammatical structures independently. Moreover, as the entrance test freshmen take a general English test, passing that test does not guarantee that students would then be able to process scientific reading materials or foreign language textbooks, which may be written for native speakers of English, let alone that they would then be able to learn a language from these materials; since they may have to devote all of their cognitive resources to the comprehension and study of the subject matter.

PU would be wise to address the issue of the entry requirements for students. It appears that at present, with English proficiency levels of students being on the low side when graduating from high school, it is currently PU's own responsibility to prepare freshmen well for EMI / CLIL education via intensive English courses, as is done already now. Furthermore, PU may be advised to opt for a more gradual build-up of the EMI program, with more courses being taught in Vietnamese in the freshmen year, but with a gradual reduction of Vietnamese medium courses in the sophomore year, to end with a full English-medium program during the students' graduation years.

Our findings regarding lecturers' use of English during EMI courses give food for thought. If it is PU's strategy and ambition to allow its outgoing graduates to participate in EMI master programs overseas, or to attract incoming foreign students who are not yet able to speak or read Vietnamese in their High Quality and Advanced Programs, major changes in current teaching approaches are needed. Indeed, the only way to attract foreign students would be to teach EMI fully in English, to provide English-medium descriptions of courses and course procedures, and to demand English entry levels that are not below the CEFR.

B1; and preferably the B2 level, especially for advanced courses. It follows from this these lecturers should be able to provide proof of their mastery of English at the CEFR C1 level, by successfully completing an internationally recognized English language test, but especially by demonstrating their mastery of the language in their teaching. In addition, lecturers need to be familiar with CLIL 
teaching strategies and to be able to implement them during their courses, so that students can integrate the learning of specialized vocabulary with content learning and can practice and further enhance their critical thinking and academic presentation skills in the English language.

Nevertheless, it is important to strike a good balance between using Vietnamese and English in courses where not all the students have mastered the English language well enough. If lecturers decide to explain difficult concepts and procedures in Vietnamese, so as to prevent subject content loss, this strategy may be wholly appropriate, especially in view of the fact that universities, like the one under scrutiny in this study, face the danger of having larger groups of students who opt out of EMI programs; because they experience them as being too far above their current abilities. This might damage PU's reputation as a university where it is said that excellent conditions are in place for supporting students to learn.

Furthermore, it may be advisable to develop a CLIL methodology course for content lecturers, and to provide them with personalized CLIL teaching support at their request. This approach could lead to true CLIL teaching, in which the learners can learn both precise subject matter contents and accurate academic and professional English in an integrated way. In this way, they would be able to enjoy participating actively in EMI courses; and they could also acquire what is said to be typically Anglo-Saxon academic and professional skills. Furthermore, students should receive dedicated instructions on how to best learn in EMI courses, learning-appropriate strategies to read English-medium academic texts, so that they can maximize their understanding and application of subject matter, whilst also enlarging their discipline-related and academic lexicon and language skills.

A limitation of this study lay in the number of respondents it could attract. Only 104 respondents participated in the investigation. Following this, we could not explore potential differences between the various subgroups of students, for example with respect to age, number of years of EMI-experience or disciplinary field. Even if we are well-aware of the fact that we have mapped students' perceptions only and have not had the opportunity to actually attend EMI classrooms for a limited number of times, we are confident that students' answer reliability mirrors, which reflect the actual teaching situation at PU, as they confirm what we observed during our own classroom observations.

In future, via the collection of more and more longitudinal data, it should be possible to determine when students become truly ready for CLIL teaching; and when perhaps the teaching rhythm could be accelerated. When lecturers could be given the guarantee that an initial slowdown in learning within a CLIL context, especially in the first years of university study, this would surely be followed by more substantial learning in which the contents and the language are integrated, they may be more motivated to teaching according to CLIL methodology, leaving EMI teaching, which may actually be a more Vietnamese-medium teaching than the EMI-teaching, behind them.

In the future, it would also be interesting to study to what extent high school students, who have graduated from the schools for the gifted and have entered 
EMI courses at PU for the first time in the schoolyear 2020-2021 do better than students who did not attend such CLIL secondary schools before entering an EMI program at PU. The question to be answered is whether the effort these high school students have made to study mathematics, physics and chemistry in English has really been worthwhile? Do students who take an intensive English course during the first year of their university education not keep up with these students as regards their mastery of the English language, or worse, would they surpass them in terms of content learning? Would all these students remain motivated to support CLIL learning?

Does their motivation fluctuate, and if so, why? Are they able to maintain the image of an ideal self? (Dörnyei \& Ushioda, 2009). Here, we are referring to one who can participate with ease in the international academic community? Would they go to study further abroad, and thus contribute to Vietnam's reputation as a reliable business partner?

\section{Conclusion}

The study reported here has looked into CLIL implementation realities against the background of MOET's project "Teaching and Learning Foreign Languages in the National Educational System, Period 2008-2020", which has now come to an end. Even if the government has been successful in establishing a sense of urgency regarding the need to integrate in the international research and teaching community in HEIs, it has not been fully efficient when it comes to stimulating the necessary preparatory work that HEIs need to do before starting with such an important reform, which touches the heart of education, as it affects the degree of comprehensibility of communication in HEI courses (Tran \& Marginson, 2018). Our study reveals that actual teaching reality may still be far removed from the desired reality, namely that lecturers are fully able to teach content courses in English and that students are wholly ready to participate in these courses. From the data, it is clear that lecturers are devoted to content teaching and that students appreciate their efforts. However, the case of PU has shown that sustainable CLIL teaching also depends on improved students' and lecturers' preparation. One thing that practitioners should take to heart, is to inform students of the language level required for successful participation in the course.

Open communication may motivate students to try and achieve the desired ELP level before entering the CLIL program. Another thing is to support students in the acquisition of CLIL learning skills through systematically directing students' attention to important content and language features throughout their courses, in order to best serve their students, lecturers would be wise to devote themselves to the acquisition of CLIL teaching methodology, including the preparation of teaching materials and the selection of teaching formats.

\section{References}

Aguilar, M., \& Rodríguez, R. (2012). Lecturer and student perceptions on CLIL at a Spanish university. International Journal of Bilingual Education and Bilingualism, 15(2), 183-197. https:/ / doi.org/10.1080/13670050.2011.615906

Coyle, D., Hood, P., \& Marsh, D. (2010). Content and Language Integrated Learning (3rd ed.). Cambridge University Press. www.cambridge.org/9780521130219 
Do, H. M., \& Le, L. T. D. (2017). Content lecturers' challenges in EMI classroom. European Journal of English Language Teaching, 2(1), 1-21. https://doi.org/10.5281/zenodo.256802

Dörnyei, Z., \& Ushioda, E. (2009). Motivation, language identity and the L2 self (Vol. 36). Multilingual Matters Bristol.

Fajardo Dack, T. M., Argudo, J., \& Abad, M. (2020). Language and Teaching Methodology Features of CLIL in University Classrooms: A Research Synthesis. Colombian Applied Linguistics Journal, 22(1 SE-Theme Review), 40-54. https://doi.org/10.14483/22487085.13878

Goris, J., Denessen, E., \& Verhoeven, L. (2019). The contribution of CLIL to learners' international orientation and EFL confidence. Language Learning Journal, 47(2), 246-256. https:// doi.org/10.1080/09571736.2016.1275034

Graham, K. M., Choi, Y., Davoodi, A., Razmeh, S., \& Dixon, L. Q. (2018). Language and Content Outcomes of CLIL and EMI: A Systematic Review. Latin American Journal of Content $\mathcal{E}$ Language Integrated Learning, 11(1), 19-38. https://doi.org/10.5294/lacli1.2018.11.1.2

Macaro, E., Curle, S., Pun, J., An, J., \& Dearden, J. (2018a). A systematic review of English medium instruction in higher education. Language Teaching, 51(1), 36-76. https://doi.org/10.1017/S0261444817000350

Marsh, D., Mehisto, P., Wolff, D., \& Frígols-Martín, M. J. (2012). European Framework for CLIL Teacher Education. A framework for the professional development of CLIL teachers. In Encuentro (Vol. 21). https:/ / doi.org/10.1017/S0261444811000243

McKinley, J., \& Rose, H. (2019). The routledge handbook of research methods in applied linguistics. In The Routledge Handbook of Research Methods in Applied Linguistics. Routledge. https://doi.org/10.4324/9780367824471

Nguyen, H. T. (2018). English-medium-instruction management: The missing piece in the internationalisation puzzle of Vietnamese higher education. Internationalisation in Vietnamese higher education (pp. 119-137). Springer. https:/ / doi.org/10.1007/9783-319-78492-2_7

Nuñez Asomoza, A. (2015). Students' perceptions of the impact of CLIL in a Mexican BA program. Profile Issues in TeachersProfessional Development, 17(2), 111-124. https://doi.org/10.15446/profile.v17n2.47065

Peukert, H., \& Gogolin, I. (2017). Dynamics of Linguistic Diversity (Vol. 6). John Benjamins Publishing Company. https://doi.org/10.1075/hsld.6

Phuong, Y. H., \& Nguyen, T. T. (2019). Students' Perceptions towards the Benefits and Drawbacks of EMI Classes. English Language Teaching, 12(5), 88-100. https://doi.org/10.5539/elt.v12n5p88

Tran, L. T., \& Marginson, S. (2018). Internationalisation of Vietnamese higher education: An overview. Internationalisation in Vietnamese Higher Education, 1-16. https:// doi.org/10.1007/978-3-319-78492-2

Tran, T. T. Q., \& Phuong, H. Y. (2019). An investigation into English preparatory programs for EMI learning in higher education institutes in Vietnam. Can Tho University Journal of Science, 11(2), 51-60. https://doi.org/10.22144/ctu.jen.2019.024

Tsuchiya, K., \& Pérez Murillo, M. D. (2015). Comparing the language policies and the students' perceptions of CLIL in tertiary education in Spain and Japan. Latin American Journal of Content and Language Integrated Learning, 8(1), 25-35. https:// doi.org/10.5294/laclil.2015.8.1.3

Vu, N. T. T., \& Burns, A. (2014). English as a medium of instruction: Challenges for Vietnamese tertiary lecturers. Journal of Asia TEFL, 11(3), 1-31. http:/ / www.asiatefl.org/main/download_pdf.php?i=59\&c=1412065511\&fn=11 _3_01.pdf 


\section{Appendix 1 \\ QUESTIONNAIRE ON STUDENTS' PERCEPTIONS OF EMI AND CLIL COURSES}

This questionnaire is about the present implementation of Content and English language integrated learning and teaching at our university. We hope that you can give your feedback on specialized subjects taught in English. Therefore, your answers will help our university to improve the quality and the effectiveness of your academic discipline courses taught in English in the future.

The main objective of this questionnaire is to gather information about your impressions and reactions to content and knowledge teaching in English. This questionnaire is anonymous and confidential. The obtained information will be only used for research purposes. Your responses will NOT be passed on to your instructors.

Thank you very much for your collaboration.

Section 1: Student's Background

\begin{tabular}{|l|l|}
\hline 1. Student's Email & \\
\hline 2. Your major: & \\
\hline 3. Your age: & \\
\hline 4. Your faculty / college: & \\
\hline
\end{tabular}

Section 2: Your mastery of English

\begin{tabular}{|l|l|}
\hline $\begin{array}{l}\text { 5.Do you hold any English } \\
\text { certificate and if yes, which } \\
\text { exactly? }\end{array}$ & \\
$\begin{array}{l}\text { (e.g. A2/KET ; B1/ PET, B2 } \\
\text { (FCE); C1 (CAE); IELTS, } \\
\text { TOEIC, TOFLE) }\end{array}$ & \\
\hline $\begin{array}{l}\text { 6.What is your level of } \\
\text { English proficiency? }\end{array}$ & $\begin{array}{l}\text { Beginner / A1 } \\
\text { Intermediate/B1 } \square \\
\text { Upper-Intermediate / B2 } \square \quad \text { Advanced/ C1 } \\
\text { Proficiency/ C2 } \square\end{array}$ \\
\hline $\begin{array}{l}\text { 7. How would you rate } \\
\text { your English proficiency } \\
\text { related to your specific field } \\
\text { of study? }\end{array}$ & $\begin{array}{l}\text { 1.poor } \square \text { 2.fair } \square 3 . g o o d \square \\
\text { excellent } \square\end{array}$ \\
\hline
\end{tabular}


Section 3: How would you evaluate the following course tasks and teaching activities?

\begin{tabular}{|l|l|l|l|l|l|}
\hline & $\begin{array}{l}\text { Not } \\
\text { useful } \\
\text { at all }\end{array}$ & $\begin{array}{l}\text { Slightly } \\
\text { useful }\end{array}$ & $\begin{array}{l}\text { Quite } \\
\text { useful }\end{array}$ & Useful & $\begin{array}{l}\text { Extremely } \\
\text { useful }\end{array}$ \\
\hline $\begin{array}{l}\text { 8. Presentations related to } \\
\text { content-subject issues }\end{array}$ & & & & & \\
\hline $\begin{array}{l}\text { 9. Group work to analyse and } \\
\text { discuss issues related } \\
\text { to your scientific field. }\end{array}$ & & & & & \\
\hline $\begin{array}{l}\text { 10. Individual project to present } \\
\text { or report issues related to your } \\
\text { scientific field. }\end{array}$ & & & & & \\
\hline $\begin{array}{l}\text { 11. Oral presentations on issues } \\
\text { related to your scientific field }\end{array}$ & & & & & \\
\hline $\begin{array}{l}\text { 12. Recording students' views } \\
\text { according to their oral } \\
\text { presentations }\end{array}$ & & & & & \\
\hline $\begin{array}{l}\text { 13. Assessing and discussing } \\
\text { presentations made by other } \\
\text { groups. }\end{array}$ & & & & & \\
\hline $\begin{array}{l}\text { 15. Projects relevant to your } \\
\text { scientific field. } \\
\text { carry out projects relevant to }\end{array}$ & & & & & \\
\hline $\begin{array}{l}\text { your scientific field. } \\
\text { 16. Prientific texts. }\end{array}$ & & & & & \\
\hline
\end{tabular}

17. What is the percentage of teaching time that is carried through in English?

18. The integrated content and English learning has helped me improve my English-language skills

Strongly disagree $\square$ disagree $\square \quad$ neutral $\square \quad$ agree $\square \quad$ strongly agree 
19. The integrated content and English learning has helped me to develop my knowledge in other content courses also.

Strongly disagree $\square$ disagree $\square \quad$ neutral $\square \quad$ agree $\square \quad$ strongly agree

\section{Section 4: Your instructors/lecturer' English language proficiency}

20.I think that the instructors teaching my subject-content courses have excellent English language competence

Strongly disagree $\square$ disagree $\square \quad$ neutral $\square$ agree $\square$ strongly agree

\begin{tabular}{|l|l|l|l|l|l|}
\hline $\begin{array}{l}\text { When your teacher } \\
\text { speaks in English in CLIL } \\
\text { class, what do you } \\
\text { consider important? }\end{array}$ & $\begin{array}{l}\text { Not at all } \\
\text { important }\end{array}$ & $\begin{array}{l}\text { Very } \\
\text { unimportant }\end{array}$ & $\begin{array}{l}\text { Neither } \\
\text { important } \\
\text { nor } \\
\text { unimportant }\end{array}$ & important & $\begin{array}{l}\text { Extremely } \\
\text { Important }\end{array}$ \\
\hline $\begin{array}{l}\text { 21. the correct } \\
\text { pronunciation of words }\end{array}$ & & & & & \\
\hline $\begin{array}{l}\text { 22. teachers' explanations } \\
\text { and instructions }\end{array}$ & & & & & \\
\hline $\begin{array}{l}\text { 23. knowledge of } \\
\text { vocabulary }\end{array}$ & & & & & \\
\hline $\begin{array}{l}\text { 24. knowledge of the } \\
\text { contents }\end{array}$ & & & & & \\
\hline $\begin{array}{l}\text { 25. the use of facial } \\
\text { expressions, gestures and } \\
\text { body movements }\end{array}$ & & & & & \\
\hline $\begin{array}{l}\text { 26. grammatical } \\
\text { correctness }\end{array}$ & & & & & \\
\hline $\begin{array}{l}\text { 27. check that the others } \\
\text { understand me when I } \\
\text { speak }\end{array}$ & & & & & \\
\hline $\begin{array}{l}\text { 28. the ability to } \\
\text { reformulate (e.g. teacher } \\
\text { can change and modify } \\
\text { questions, teaching } \\
\text { instructions, plans for } \\
\text { students Understanding } \\
\text { the contents }\end{array}$ & & & & & \\
\hline $\begin{array}{l}\text { 29.Others: } \\
\text { noding }\end{array}$ & & & & & \\
\hline
\end{tabular}




\begin{tabular}{|c|c|c|c|c|c|}
\hline \multicolumn{6}{|c|}{ Section 4: Teaching materials } \\
\hline Statements & $\begin{array}{l}\text { strongly } \\
\text { disagree }\end{array}$ & disagree & Neutral & agree & $\begin{array}{l}\text { Strongly } \\
\text { agree }\end{array}$ \\
\hline $\begin{array}{l}\text { 30. The present materials } \\
\text { can satisfy language and } \\
\text { content- teaching equally. }\end{array}$ & & & & & \\
\hline $\begin{array}{l}\text { 31. The content element } \\
\text { outweighs the language } \\
\text { element in the current } \\
\text { materials. }\end{array}$ & & & & & \\
\hline $\begin{array}{l}\text { 32.Language element } \\
\text { outweighs content } \\
\text { element in the current } \\
\text { materials. }\end{array}$ & & & & & \\
\hline $\begin{array}{l}\text { 33. The current materials } \\
\text { systematically foster } \\
\text { English proficiency. }\end{array}$ & & & & & \\
\hline $\begin{array}{l}\text { 34. The current materials } \\
\text { foster learning skills } \\
\text { development. } \\
\text { (e.g. They can improve } \\
\text { the way you study } \\
\text { subject-content and } \\
\text { English) }\end{array}$ & & & & & \\
\hline $\begin{array}{l}\text { 35. The current materials } \\
\text { foster learners' } \\
\text { autonomy. } \\
\text { (e.g. You have the ability } \\
\text { to study English and } \\
\text { contents in an integrated } \\
\text { way by making use of my } \\
\text { free time to study, } \\
\text { keeping a record of my } \\
\text { study, opting out of class } \\
\text { activities to practice, } \\
\text { catching chances to take } \\
\text { part in activities such as } \\
\text { pair/ group discussion.) }\end{array}$ & & & & & \\
\hline $\begin{array}{l}\text { 36. The current materials } \\
\text { foster cooperative } \\
\text { learning. }\end{array}$ & & & & & \\
\hline
\end{tabular}




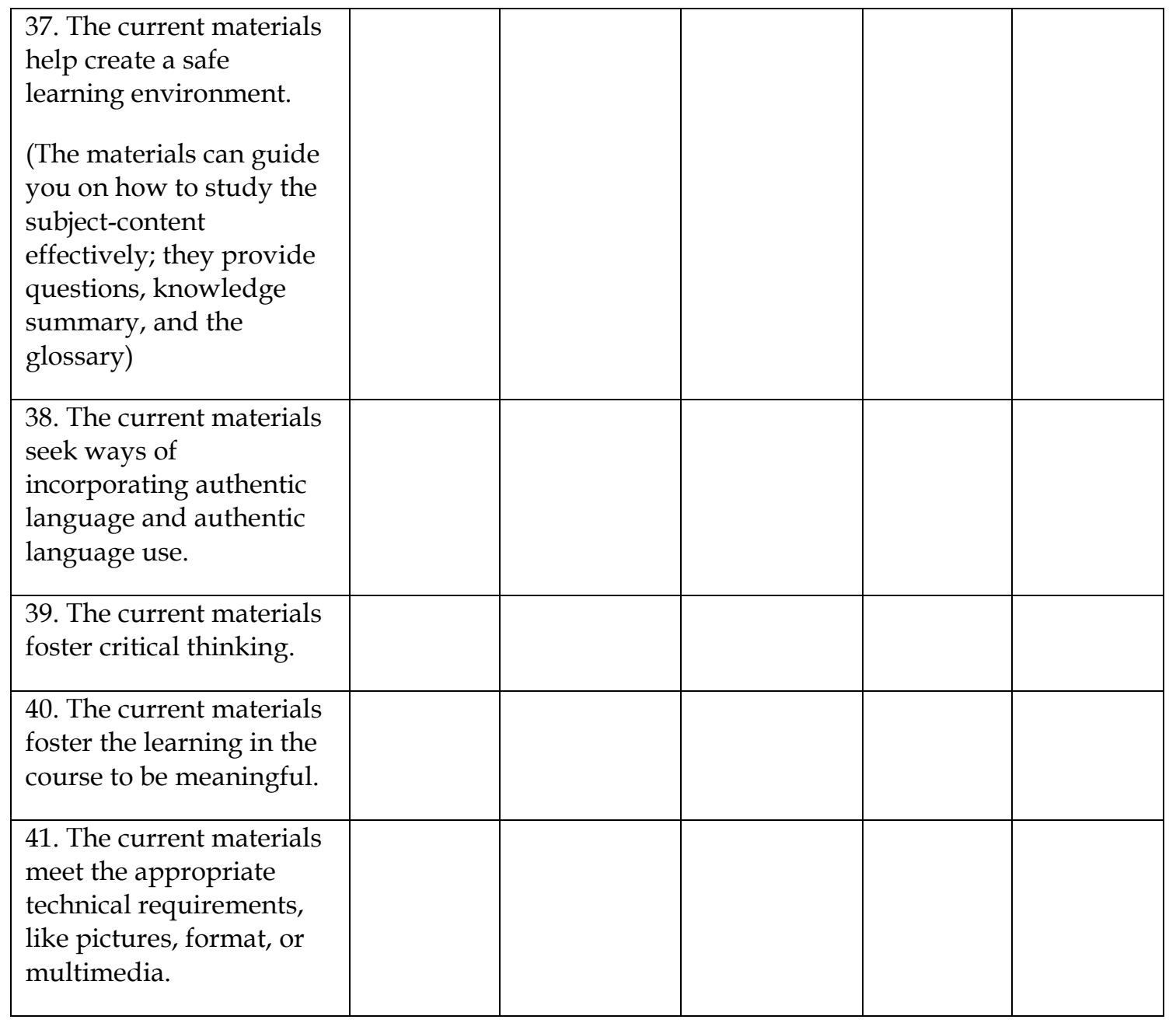

